Article

\title{
Greenhouse Gas Emission Assessment from Electricity Production in the Czech Republic
}

\author{
Simona Jursová ${ }^{1, *}$, Dorota Burchart-Korol ${ }^{2}$, Pavlína Pustějovská ${ }^{1}$, Jerzy Korol ${ }^{3}$ and \\ Agata Blaut ${ }^{3}$ \\ 1 Centre Enet, VSB-Technical University of Ostrava, 70833 Ostrava, Czech Republic; \\ pavlina.pustejovska@vsb.cz \\ 2 Faculty of Transport, Silesian University of Technology, 40-019 Katowice, Poland; \\ dorota.burchart-korol@polsl.pl \\ 3 Department of Material Engineering, Department of Water Protection, Central Mining Institute, \\ 40-166 Katowice, Poland; jkorol@gig.eu (J.K.); ablaut@gig.eu (A.B.) \\ * Correspondence: simona.jursova@vsb.cz; Tel.: +420-597-325-421
}

Received: 24 November 2017; Accepted: 22 January 2018; Published: 23 January 2018

\begin{abstract}
The paper deals with the computational life cycle assessment (LCA) model of electricity generation in the Czech Republic. The goal of the paper was to determine the environmental assessment of electricity generation. Taking into account the trend of electricity generation from 2000 to 2050, the paper was focused on electricity generation evaluation in this country in view of its current state and future perspectives. The computational LCA model was done using the Intergovernmental Panel on Climate Change (IPCC) method, which allowed the assessment of greenhouse gas emissions. For the assessment, 1 Mega-watt hour of the obtained electricity (MWhe) was used as a functional unit. The cradle-to-gate approach was employed. The system boundary covered all the technologies included in the electricity mix of the country. Resulting from the analysis, the solids, lignite in particular, was assessed as an energy source with the most negative impact on the emissions of greenhouse gas. This article results from international cooperation of a Czech-Polish team in the field of computational LCA models. It presents partial results of the team cooperation which serves as a base for following comparison of Czech and Polish systems of electricity generation.
\end{abstract}

Keywords: environment; electricity; LCA assessment; Czech Republic

\section{Introduction}

Searching for cost effective and environmentally friendly energy sources has become more critical with increasing concerns about sustainability [1]. Electricity is one of the main contributors to global environmental impacts. It is one of the main sources of environmental burden in several sectors such as buildings or information and communication technology [2]. Electricity supply is often highlighted as a significant hot spot in Life cycle assessment (LCA) results for a majority of product and service life cycles [3]. The method of LCA is one of the most effective tools being used to provide a material and energy balance over the entire life of a material, product, technology, or service, determining its interaction with its environment, and assessing its impacts on the environment [4]. It has its roots in a number of studies conducted in the 1960s and 70s that aimed at optimizing energy consumption in a context where the latter represented a restraint for the industry. Since then, LCA has been further developed and standardized but its core aim has always remained to understand the overall environmental impacts of a product or system along its full lifecycle (from the extraction of the necessary primary resources, to end-of-life disposal, and recycling where applicable) [5]. There are studies, following LCA analysis, which are aimed at possibilities of further product utilization, e.g., into segments of construction materials [6-8]. 
The life cycle assessment (LCA) can support the elaboration of policies to meet global or regional challenges. It can also allow for the identification of hotspots and the refining of existing energy policies, e.g., supporting amendments in national emission standards and prioritizing or targeting specific energy sources and technologies identified as important causes of environmental impact in the countries considered. The LCA is a systemic tool and is, thus, highly relevant for evaluating long-term electricity trajectories, which can encompass all electricity supply systems and their interactions with other systems and society at large $[9,10]$.

In the field of power engineering, this method has been used globally. The reference literature shows results of LCA of individual energy sources and technologies. The assessment of electricity system generation in general view of energy sources has been carried out for many countries such as China, UK, USA, Portugal, Romania, Poland, Mexico, Mauritius, and Tanzania [11-17]. Some authors assessed electricity generation in view of greenhouse gas emissions (GHGs) [18,19]. Some authors studied on environmental impact of electricity generation from renewable resources [20-27]. There are also papers that have assessed clean and innovative power technologies [28-31]. In the case of the Czech Republic, there is a lack of papers concerning the LCA of energy systems. Only the results of the LCA analyses of municipal waste management in the Czech Republic are presented in literature [32]. This paper's objective is to provide an environmental assessment of energy sources used for electricity generation in the Czech Republic. Its purpose is the assessment of applied energy sources and interpretation of their environmental effect in current and future perspectives.

\section{Materials and Methods}

Environmental assessment has been carried out for electricity generation in the Czech Republic; a country located in central Europe with a population of over 10 million inhabitants. The country's surface area is $78,866 \mathrm{~km}^{2}$. The Czech Republic is one of the most industrialized economies and developed in the Central and Eastern Europe. The Czech electricity market is characterized by a very positive attitude towards nuclear power, a dominant position of lignite in the Czech Republic electricity generation, and a strong role of electricity export since the Czech Republic ranks sixth in the world and fourth in Europe in electricity exports [33]. The dominant source of energy in the Czech Republic is solids (hard coal and lignite), which constitutes 39\% of the total primary energy supply. The computational LCA model was based on International Organization for Standardization (ISO) ISO 14,040:2006 using SimaPro 8 software (Pré Sustainability, Amersfoort, The Netherlands) with Ecoinvent 3 database. The authors changed electricity mix from ecoinvent according to data from [34]. Reference [35] describes the principles and framework for LCA, including four stages which are presented on the Figure 1.

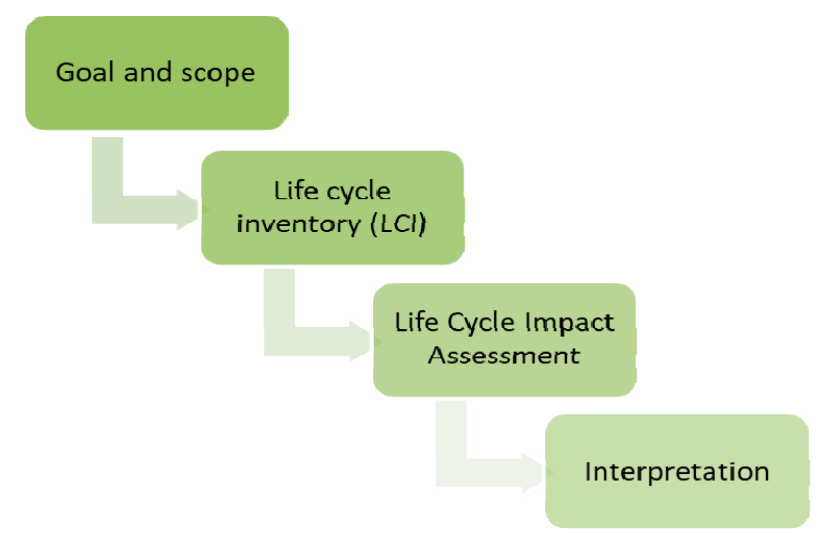

Figure 1. Stages of life cycle assessment based on [35]. 
The cradle-to-gate approach was employed. The functional unit was applied as the production of 1 MWh of electricity. All input and output are indicated based on this functional unit. Environmental assessment was made using the LCA method, based on the IPCC method, allowing the presentation of greenhouse gas emissions (GHGs) with life cycle approach. IPCC method was developed by the Intergovernmental Panel on Climate Change (IPCC). The IPCC publishes Global Warming Potentials (GWPs) [36]. GHG emissions from analyzed systems were quantified per unit of electricity. The impact category refers to GHGs and expresses the radiative forcing of greenhouse gas emissions over a 100-year horizon, expressed in kilograms of $\mathrm{CO}_{2}$ equivalent. The life cycle greenhouse gas emission involves analysis the GWPs of energy sources through life cycle assessment of energy sources for electricity generation.

For the purpose of computational environmental life cycle assessment model, data for the current and future electricity generation in the Czech Republic were identified in European and global energy bases. Figure 2 shows the inventory data of electricity production from 2000 to 2050 that was required to perform the computational model.

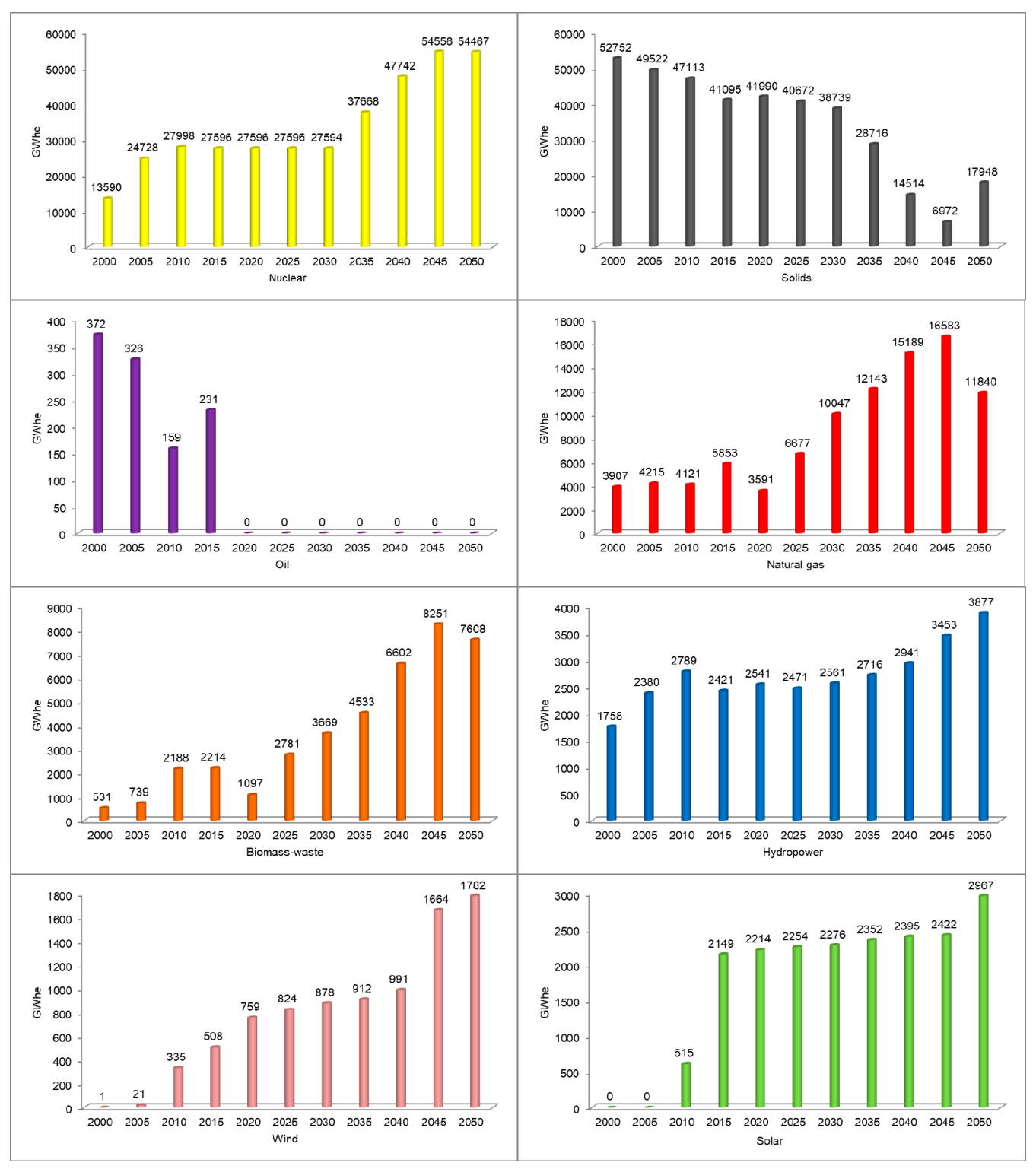

Figure 2. Live cycle inventory data for analysis, based on $[34,37]$. 
In Czech Republic, the main energy sources for electricity are solids (lignite and hard coal) and nuclear energy. The trend in 2000-2050 shows a drop from 52,752 Giga-watt hour of the obtained electricity (GWhe) to 17,948 GWhe in generation from coal and an increase from 13,590 GWhe to 54,467 GWhe in nuclear energy. Coal is the only significant indigenous energy resource in the Czech Republic. The country's proven coal reserves have been estimated at some 880 million tonnes. Hard coal accounts for $10 \%$, while lignite presents more than $90 \%$ of these reserves. Lignite provides an important contribution to the country's energy supply. The largest lignite deposit in the Czech Republic holds reserves of 750 million tonnes of good quality coal with an energy content of up to $17,500 \mathrm{~kJ} / \mathrm{kg}$. These reserves are estimated to last for the next 100 years, subject to mining limits set in 1991 [38].

The nuclear sources in the Czech Republic are primarily used for generation of electricity. These now supply $32 \%$ of all electricity produced in the country. There are two nuclear power plants in the Czech Republic, in Dukovany and in Temelin. One of the priorities of the State Energy Policy is the completion of the construction of additional nuclear power units to produce around 20 Terra-watt hour (TWh by 2035, extending the lifetime of the existing four units in the Dukovany power plant and later the possible construction of another unit to compensate for the commissioning of this plant. In the long term strategy, nuclear energy is supposed to provide electricity in excess of $50 \%$ to replace a large proportion of the coal sources. Sites for future additional nuclear power stations in the Czech Republic after 2040 are being explored and prepared [39].

Oil and gas deposits are insignificant in the Czech Republic. From 2020, oil is not expected to be used in the Czech Republic for the production of electricity. The current ratio of gas to electricity generation is roughly $3 \%$. The domestic energy system is practically entirely dependent on imports of this energy commodity. The dominant supplier is the Russian Federation, together with Norway. In long term strategy, electricity from natural gas is expected to be generated in cogeneration. The Czech Republic in its energy policy assumes the development of so-called micro cogeneration sources, primarily using natural gas [39]. The total proportion of gas in the energy mix therefore rises after 2020. In 2050, gas fired generation is expected to be partially replaced by solids and decline to 11,840 GWhe.

The decline in the ratio of domestic energy sources to the electricity generation from primary energy sources inevitably leads to the development of low-carbon ones. The Action Plan for Biomass in the Czech Republic legislatively supports the development of electricity generation from biomass and waste until domestic potential will have been exhausted [40]. In long term strategy, the biodegradable municipal waste is expected to replace primary sources. Currently, $500 \mathrm{~kg}$ of municipal waste is generated per inhabitant of the Czech Republic per year. The amount of waste rises as the population's purchasing power increases. Nowadays, there are only three waste energy utilization facilities in the Czech Republic, with a processing capacity of 654 tonnes per year [39].

Czech geographic conditions allow the installation of renewable energy plants which make use of weather, like wind or sun. However, due to the natural environment, these types of plants yield only average results. Although renewable energy sources are not competitive on their own and the support for every MWh of the green energy produced and supplied to the grid is necessary, the increasing trend in electricity generated in wind and solar plants is visible in following years until 2050. In 2015, there was a sharp rise in the use of solar energy for electricity production due to the disproportionate amount of support for newly built commercial plants from 2006-2010. Before legislation reacted to the photovoltaic boom (by the end of 2010), the Czech installed solar capacity rose from $40 \mathrm{MW}$ in 2008 to 1960 MW in 2010. The Czech subsidy for solar electricity dropped from an initial 15,565 Czech crowns (CZK)/MWh in 2006 to zero for newly built commercial photovoltaic plants in 2014 [33].

Distribution of energy sources on electricity generation in the Czech Republic is in Figure 3. Renewable energy represents $12 \%$ of the total amount of 82.6 TWh of electricity generated in 2015 . In comparison with the average of International Energy Agency countries, it is a half share. In the European Union (EU) in 2015, the main sources of electricity included nuclear energy 867,402 GWhe (which constituted 26.68\%), solids 846,834 GWhe (which constituted 26.04\%), and natural gas 
566,075 GWhe (which constituted $17.41 \%$ ). Renewable energy sources accounted for $28.2 \%$ of electricity generation in total.
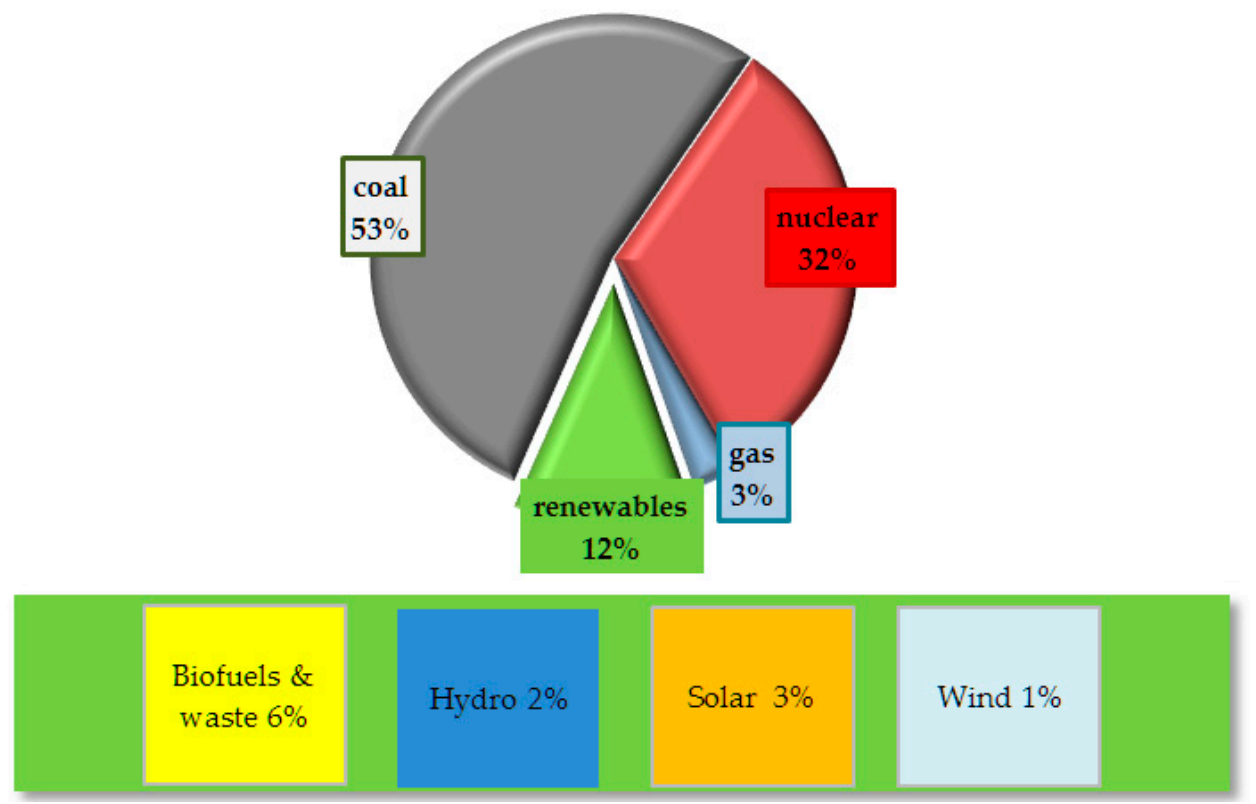

Figure 3. Distribution of energy sources on electricity generation in Czech Republic based on [41].

In the EU, wind and hydro plants provide the largest contribution from these sources, supplying $19 \%$ of gross electricity generation in 2015. Generation from solar sources contributes $3 \%$. The investments into solar plants are expected in Southern Europe to reach an installed capacity of 183 GW by 2030 and 299 GW by 2050 [34]. Also, the use of biomass and waste combustion for power generation is expected to increase over time, both in pure biomass plants and cofiring applications in solid fuel plants. The current biomass and waste contribution to electricity generation in European Union is $6 \%$. The share of geothermal electricity generation in long time European strategy remains at $0.2 \%$. In the European Union, gas plays a crucial role in the context of emission reduction targets and increased implementation of variable renewable energy sources. Gas-fired generation is a back-up technology for variable energy sources.

Electricity generation from solids in European Union declines significantly in the projection period from 2000-2050. The same trend is recorded in energy strategy of the Czech Republic. At the end of projection time, share of solids in gross electricity production increases in European Union from $5.9 \%$ in 2045 to $6.1 \%$ in 2050; in the Czech Republic from $7.4 \%$ even to $17.9 \%$ [37]. It is explained by economically driven investments into clean coal technologies and technology of carbon capture and storage (CCS) which has taken place in the long term in countries such as Czech Republic with substantial solid generation and endogenous resources. According to the EU Reference Scenario, by 2050 in the European Union, more than half of solid-fuelled generation will be produced from facilities with installed CCS technologies.

\section{Results}

The comparative analysis of life cycle greenhouse gas emissions of electricity production in the Czech Republic is presented in Figure 4. The GHGs for the electricity generation was $917 \mathrm{~kg} \mathrm{CO}$ eq/MWh in 2000, while in 2050 the potential impact on GHG will be $331 \mathrm{~kg} \mathrm{CO}$ eq/MWh. The value of GHG emissions from 2000 over the past 50 years decreased by $66 \%$. Table 1 then sums up calculated GHG emissions from individual energy sources. 


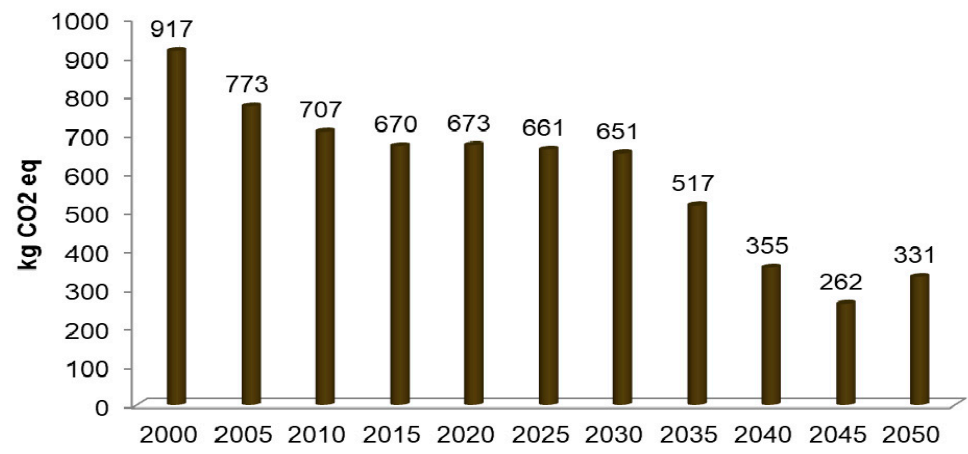

Figure 4. Analysis of greenhouse gas emissions of electricity production in the Czech Republic based on Intergovernmental Panel on Climate Change (IPCC) method.

Table 1. Greenhouse gas emission electricity production from individual energy sources in the Czech Republic in $\mathrm{kg} \mathrm{CO}_{2}$ eq.

\begin{tabular}{ccccccccccc}
\hline Year & Total & Nuclear & $\begin{array}{c}\text { Hard } \\
\text { Coal }\end{array}$ & Lignite & Oil & $\begin{array}{c}\text { Natural } \\
\text { Gas }\end{array}$ & $\begin{array}{c}\text { Biomass } \\
\text { Waste }\end{array}$ & Hydro & Wind & Solar \\
\hline 2000 & 917 & 1.45 & 112.69 & 746.98 & 6.15 & 48.97 & 0.43 & 0.09 & 0.00 & 0.00 \\
2005 & 773 & 2.35 & 94.15 & 624.03 & 4.79 & 47.01 & 0.53 & 0.11 & 0.00 & 0.00 \\
2010 & 707 & 2.56 & 86.02 & 570.10 & 2.24 & 44.14 & 1.50 & 0.12 & 0.04 & 0.62 \\
2015 & 670 & 2.62 & 77.99 & 516.98 & 3.39 & 65.17 & 1.58 & 0.11 & 0.07 & 2.25 \\
2020 & 673 & 2.69 & 81.97 & 543.32 & 0.00 & 41.13 & 0.80 & 0.12 & 0.11 & 2.39 \\
2025 & 661 & 2.58 & 76.08 & 504.22 & 0.00 & 73.27 & 1.95 & 0.11 & 0.11 & 2.33 \\
2030 & 651 & 2.51 & 70.36 & 466.33 & 0.00 & 107.05 & 2.50 & 0.11 & 0.12 & 2.28 \\
2035 & 517 & 3.30 & 50.23 & 332.96 & 0.00 & 124.62 & 2.98 & 0.11 & 0.12 & 2.27 \\
2040 & 355 & 4.12 & 25.02 & 165.80 & 0.00 & 153.58 & 4.27 & 0.12 & 0.12 & 2.28 \\
2045 & 262 & 4.53 & 11.57 & 76.65 & 0.00 & 161.37 & 5.14 & 0.14 & 0.20 & 2.22 \\
2050 & 331 & 4.22 & 27.81 & 184.39 & 0.00 & 107.67 & 4.43 & 0.14 & 0.20 & 2.54 \\
\hline
\end{tabular}

An analysis of the greenhouse gas emissions for each source of electricity in the Czech Republic was done in order to determine the environmental determinants of the impacts. The determinants of the GHG emissions of current and future electricity generation in the Czech Republic are presented in Figure 5 .

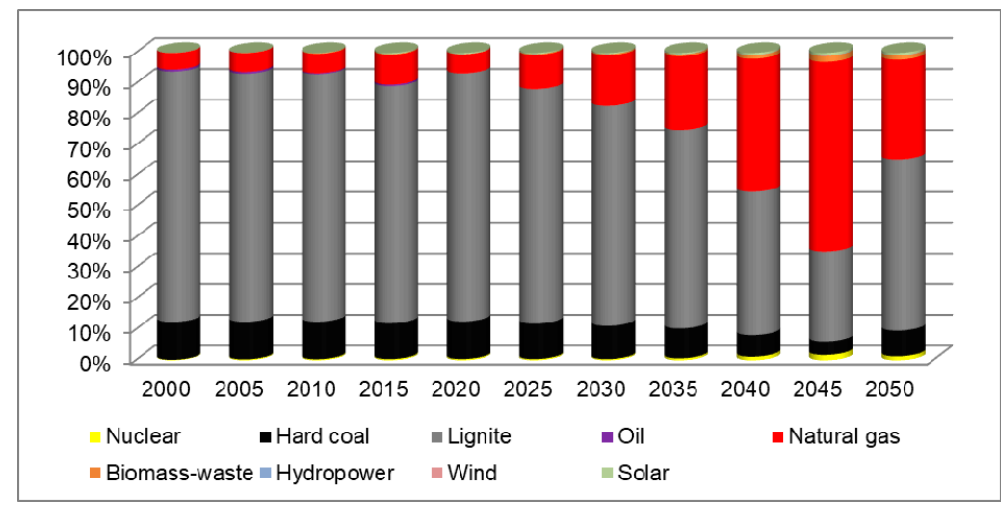

Figure 5. Determinants of greenhouse gas (GHG) emissions of current and future electricity generation in the Czech Republic based on IPCC method.

\section{Discussion}

The environmental assessment of Czech electricity sources shows that the greenhouse gas (GHG) emissions are determined by generation from solids, in particular lignite. The share of solids in the 
electricity generation system in the Czech Republic is mostly lignite over the analyzed period. It shows that electricity generation from lignite is associated with high impact in greenhouse gas emissions. The analyses that were carried out have shown that, despite the decreasing tendency of environmental impact, a slight increase related to the emissions of greenhouse gas was indicated between 2045 and 2050. This is due to an increase in the share of lignite and hard coal in the electricity generation structure in 2050 compared to 2045, as shown in Figure 2. It is predicted to increase from 67,972 GWhe to 17,948 GWhe. The increasing tendency is expected in relation with implementation of clean coal technologies such as coal gasification in integrated gas combined cycle (IGCC), in atmospheric fluidized bed (AFB), or pressurized fluidized-bed combustion (PFBC). These technologies are regarded to be more environmentally friendly in comparison to conventional coal power plants due to their high thermal efficiency, capability to process low grade coal, and low non-carbon GHG emissions. In this period, the technology of carbon capture storage (CCS) is supposed to be implemented in some power plants to prevent $\mathrm{CO}_{2}$ from entering the atmosphere. The vision of establishment of efficient high-tech technologies changes the approach to solids, resulting in increasing electricity generation from this indigenous resource in the Czech Republic. Electricity generation from solids after 2050 remain a leading source in GHG emissions predicted to emit $212.2 \mathrm{kgCO}_{2 \text { eq }}$ (Table 1) for 17,948 GWhe (Figure 2) of electricity in 2050. Since 2000, GHG emissions from solids have decreased four times. The amount of predicted electricity from the source is expected to decrease just three times in this period.

This study has shown that the share of nuclear energy in electricity generation will increase in the Czech Republic. Despite the increase of nuclear energy, it is not associated with an increase in greenhouse gas emissions. In 2000, 13,590 GWhe of electricity was produced in Czech nuclear plants and only $1.45 \mathrm{kgCO}_{2 \mathrm{eq}}$ was emitted. The nuclear electricity presents about $32 \%$ in electricity mix of the Czech Republic. GHG emissions $2.62 \mathrm{kgCO}_{2 \mathrm{eq}}$ indicated for this distribution are insignificant. By 2050, GHG emissions from nuclear source are predicted to be $4.22 \mathrm{kgCO}_{2 \mathrm{eq}}$ for a quadruple increase in electricity generated at 54,467 GWhe. Electricity generation from solids reached a similar value $(52,752 \mathrm{GWhe})$ in 2000 and presented $859.67 \mathrm{kgCO}_{2 \mathrm{eq}}$ of GHG emissions.

The trend similar to electricity from nuclear plants is recorded in the case of hydropower energy, solar, and wind. Electricity generation from these sources has an increasing tendency which does not result in a significant increase in GHG emissions. In consideration of renewable resources, the least ecological one is solar energy. An analysis of environmental determinants has shown that electricity generation in solar plants relates to largest GHG emissions in group of green energy sources. GHG emissions from solar energy are expected $2.54 \mathrm{kgCO}_{2 \text { eq }}$ for 2967 GWhe of electricity in 2050. To compare, similar amount of GHG emissions from nuclear energy $2.56 \mathrm{kgCO}_{2 \text { eq }}$ was in 2010 for 27,998 GWhe of electricity.

It has been reported that an increase in the natural gas source for the production of electricity affects the increase of GHG emissions. The ratio in GHG emissions of natural gas is expected to increase significantly from 2040 to 2050. In 2045, emissions are expected to reach $161.37 \mathrm{kgCO}_{2 \mathrm{eq}}$. In this year, the electricity generation from natural gas is predicted to overcome emissions from solid sources related to the significant decline in electricity production from solids predicted for this year.

\section{Conclusions}

Based on analysis, inventory data for electricity generation in the Czech Republic were identified. The main energy sources in the Czech Republic are nuclear energy, lignite, and hard coal. The trend in the years 2000-2050 shows an increase in nuclear energy and a decrease in electricity generation from coal. Oil is not expected to be used in the Czech Republic for the production of electricity from 2020. An increase in generation from wind, gas, solar, and biomass is expected in the following years until 2050.

Despite the reduction in the share of lignite and hard coal in the electricity generation system in the Czech Republic, the share of solids has the greatest impact on the greenhouse gas emissions. 
The obtained results show that the determinant of the greenhouse gas emissions from electricity generation systems is electricity from lignite. Despite a significant increase of nuclear power in electricity generation systems, this source does not affect the greenhouse gas emissions.

Acknowledgments: This paper was written within the framework of the project LO1404: Sustainable development of Centre of Energy Units for Utilization of non-Traditional Energy Sources (ENET) and supported by project Interreg V-A Czech Republic-Poland, Microprojects Fund 2014-2020 in the Euroregion Silesia reg. no. CZ.11.4.120/0.0/0.0/16_013/0000653.

Author Contributions: Simona Jursová and Dorota Burchart-Korol conceived the idea and designed the framework for the analysis. Agata Blaut and Pavlína Pustějovská prepared inventory data analysis. Dorota Burchart-Korol performed software assessment; Agata Blaut contributed analysis tools. Jerzy Korol and Pavlína Pustějovská interpreted the results. Simona Jursova wrote the paper. Dorota Burchart-Korol and Jerzy Korol summed up the conclusions.

Conflicts of Interest: The authors declare no conflict of interest.

\section{References}

1. Weldu, Y.W.; Assefa, G. The search for most cost-effective way of achieving environmental sustainability status in electricity generation: Environmental life cycle cost analysis of energy scenarios. J. Clean. Prod. 2017, 142, 2296-2304. [CrossRef]

2. Astudillo, M.F. Life cycle inventories of electricity supply through the lens of data quality: Exploring challenges and opportunities. Int. J. Life Cycle Assess. 2017, 22, 374-386. [CrossRef]

3. Treyer, K.; Bauer, C. Life cycle inventories of electricity generation and power supply in version 3 of the ecoinvent database-Part II: Electricity markets. Int. J. Life Cycle Assess. 2014. [CrossRef]

4. Asif, M.; Dehwah, A.H.A.; Ashraf, F.; Khan, H.S.; Shaukat, M.M.; Hassan, M.T. Life Cycle Assessment of a Three-Bedroom House in Saudi Arabia. Environments 2017, 4, 52. [CrossRef]

5. Raugei, M.; Leccisi, E. A comprehensive assessment of the energy performance of the full range of electricity generation technologies deployed in the United Kingdom. Energy Policy 2016, 9, 46-59. [CrossRef]

6. Václavík, V.; Valíček, J.; Dvorský, T.; Hryniewicz, T.; Rokosz, K.; Harničárová, M.; Kušnerová, M.; Daxner, J.; Bendová, M. A method of utilization of polyurethane after the end of its life cycle. Rocznik Ochrony Środowiska 2012, 14, 96-106.

7. Dvorský, T.; Václavík, V.; Šimíček, V.; Břenek, A. Research of the Use of Waste Rigid Polyurethane Foam in the Segment of Lightweight Concretes. Inzynieria Mineralna 2015, 36, 51-56.

8. Břenek, A.; Öchsner, A.; Václavík, V.; Altenbach, H.; Dvorský, T.; Daxner, J.; Dirner, V.; Bendová, M.; Harničárová, M.; Valíček, J. Capillary Active Insulations Based on Waste Calcium Silicates. Adv. Struct. Mater. 2015, 70, 177-188.

9. Günkaya, Z.; Özdemir, A.; Özkan, A.; Banar, M. Environmental Performance of Electricity Generation Based on Resources: A Life Cycle Assessment Case Study in Turkey. Sustainability 2016, 8, 1097. [CrossRef]

10. Laurent, A.; Espinosa, N. Environmental impacts of electricity generation at global, regional and national scales in 1980-2011: What can we learn for future energy planning? Energy Environ. Sci. 2015, 8, 689-701. [CrossRef]

11. Ou, X.; Yan, X.; Zhang, X. Life-cycle energy consumption and greenhouse gas emissions for electricity generation and supply in China. Appl. Energy 2011, 88, 289-297. [CrossRef]

12. Garcia, R.; Marques, P.; Freire, F. Life-cycle assessment of electricity in Portugal. Appl. Energy 2014, 134, 563-572. [CrossRef]

13. Stamford, L.; Azapagic, A. Life cycle sustainability assessment of UK electricity scenarios to 2070. Energy Sustain. Dev. 2014, 23, 194-211. [CrossRef]

14. Peiu, N. Life cycle inventory study of the electrical energy production in Romania. Int. J. Life Cycle Assess. 2007, 12, 225-229. [CrossRef]

15. Felix, M.; Gheewala, S.H. Environmental assessment of electricity production in Tanzania. Energy Sustain. Dev. 2012, 16, 439-447. [CrossRef]

16. Santoyo-Castelazo, E.; Gujba, H.; Azapagic, A. Life cycle assessment of electricity generation in Mexico. Energy 2011, 36, 1488-1499. [CrossRef]

17. Brizmohun, R.; Ramjeawon, T.; Azapagic, A. Life cycle assessment of electricity generation in Mauritius. J. Clean. Prod. 2014, 16, 1727-1734. [CrossRef] 
18. Jones, C.; Gilbert, P.; Raugei, M.; Mander, S.; Leccisi, E. An approach to prospective consequential life cycle assessment and net energy analysis of distributed electricity generation. Energy Policy 2017, 100, 350-358. [CrossRef]

19. Hondo, H. Life cycle GHG emission analysis of power generation systems: Japanese case. Energy 2005, 30, 2042-2056. [CrossRef]

20. Kannan, R.; Leong, K.C.; Osman, R.; Ho, H.K. Life cycle energy, emissions and cost inventory of power generation technologies in Singapore. Renew. Sustain. Energy Rev. 2007, 11, 702-715. [CrossRef]

21. Fantin, V.; Giuliano, A.; Manfredi, M.; Ottaviano, G.; Stefanova, M.; Masoni, P. Environmental assessment of electricity generation from an Italian anaerobic digestion plant. Biomass Bioenergy 2015, 83, 422-435. [CrossRef]

22. Tomasini-Montenegro, C.; Santoyo-Castelazo, E.; Gujba, H.; Romero, R.J.; Santoyo, E. Life cycle assessment of geothermal power generation technologies: An updated review. Appl. Therm. Eng. 2017, 114, 1119-1136. [CrossRef]

23. Turconi, R.; O'Dwyer, C.; Flynn, D.; Astrup, T. Emissions from cycling of thermal power plants in electricity systems with high penetration of wind power: Life cycle assessment for Ireland. Appl. Energy 2014, 131, 1-8. [CrossRef]

24. Ehtiwesh, I.A.S.; Coelho, M.C.; Sousa, A.C.M. Exergetic and environmental life cycle assessment analysis of concentrated solar power plants. Renew. Sustain. Energy Rev. 2016, 56, 145-155. [CrossRef]

25. Peric, M.; Komatina, M.; Bugarski, B.; Antonijevic, D. Best Practices of Biomass Energy Life Cycle Assessment and Possible Applications in Serbia. Croat. J. For. Eng. 2016, 37, 375-390.

26. Gu, H.M.; Bergman, R. Cradle-to-grave life cycle assessment of syngas electricity from woody biomass residues. Wood Fiber Sci. 2017, 49, 177-192.

27. Honus, S.; Kumagai, S.; Němček, O.; Yoshioka, T. Replacing conventional fuels in USA, Europe, and UK with plastic pyrolysis gases_-Part I: Experiments and graphical interchangeability methods. Energy Convers. Manag. 2016, 126, 1118-1127. [CrossRef]

28. Honus, S.; Kumagai, S.; Yoshioka, T. Replacing conventional fuels in USA, Europe, and UK with plastic pyrolysis gases-Part II: Multi-index interchangeability methods. Energy Convers. Manag. 2016, 126, 1128-1145. [CrossRef]

29. Liang, X.; Wang, Z.; Zhou, Z.; Huang, Z.; Zhou, J.; Cen, K. Up-to-date life cycle assessment and comparison study of clean coal power generation technologies in China. J. Clean. Prod. 2013, 39, 24-31. [CrossRef]

30. Burchart-Korol, D.; Korol, J.; Czaplicka-Kolarz, K. Life cycle assessment of heat production from underground coal gasification. Int. J. Life Cycle Assess. 2016, 21, 1391-1403. [CrossRef]

31. Hyder, Z.; Ripepi, N.S.; Karmis, M.E. A life cycle comparison of greenhouse emissions for power generation from coal mining and underground coal gasification. Mitig. Adapt. Strateg. Glob. Chang. 2016, 21, 515-546. [CrossRef]

32. Koci, V.; Trecakova, T. Mixed municipal waste management in the Czech Republic from the point of view of the LCA method. Int. J. Life Cycle Assess. 2011, 16, 113-124. [CrossRef]

33. Luňáčková, P.; Průša, J.; Janda, K. The merit order effect of Czech photovoltaic plants. Energy Policy 2017, 106, 138-147. [CrossRef]

34. Europe Commission. EU Reference Scenario 2016-Energy, Transport and GHG Emissions-Trends to 2050; The European Commission Report; Europe Commission: Brussels, Belgium, 2016.

35. International Organization for Standardization (ISO). 14044:2006-Environmental Management. Life Cycle Assessment. Requirements and Guidelines. Available online: https://www.saiglobal.com/pdftemp/ previews/osh/iso/updates2006/wk26/iso_14044-2006.pdf (accessed on 1 July 2006).

36. Intergovernmental Panel on Climate Change. IPCC Fifth Assessment Report. The Physical Science Basis. 2007. Available online: http:/ / www.ipcc.ch (accessed on 15 November 2017).

37. Energy Policies of IEA Countries-Czech Republic 2016. Review The International Energy Agency. Available online: http:/ / www.iea.org (accessed on 8 November 2017).

38. The Voice of Coal in Europe. Available online: https://euracoal.eu/info/country-profiles/czech-republic/ (accessed on 8 January 2018).

39. State Energy Policy of the Czech Republic. Available online: https:/ /www.mzp.cz/C125750E003B698B/en/ climate_energy/\$FILE/OEOK-State_Energy_Policy-20160310.pdf (accessed on 24 November 2017). 
40. Ministry of Agriculture of the Czech Republic. Action Plan for Biomass in the Czech Republic for the Period 2012-2020; Ministry of Agriculture: Prague, Czech Republic, 2016.

41. Czech Republic_Energy System Overview. Available online: http://www.iea.org/media/countries/ CzechRepublic.pdf (accessed on 15 November 2017). 